\title{
Public entrepreneurship as innovative management strategy in the public sector : a public choice- approach
}

Citation for published version (APA):

van Mierlo, J. G. A. (1996). Public entrepreneurship as innovative management strategy in the public sector : a public choice-approach. METEOR, Maastricht University School of Business and Economics. METEOR Research Memorandum No. 037 https://doi.org/10.26481/umamet.1996037

Document status and date:

Published: 01/01/1996

DOI:

10.26481/umamet.1996037

Document Version:

Publisher's PDF, also known as Version of record

\section{Please check the document version of this publication:}

- A submitted manuscript is the version of the article upon submission and before peer-review. There can be important differences between the submitted version and the official published version of record. People interested in the research are advised to contact the author for the final version of the publication, or visit the DOI to the publisher's website.

- The final author version and the galley proof are versions of the publication after peer review.

- The final published version features the final layout of the paper including the volume, issue and page numbers.

Link to publication

\footnotetext{
General rights rights.

- You may freely distribute the URL identifying the publication in the public portal. please follow below link for the End User Agreement:

www.umlib.nl/taverne-license

Take down policy

If you believe that this document breaches copyright please contact us at:

repository@maastrichtuniversity.nl

providing details and we will investigate your claim.
}

Copyright and moral rights for the publications made accessible in the public portal are retained by the authors and/or other copyright owners and it is a condition of accessing publications that users recognise and abide by the legal requirements associated with these

- Users may download and print one copy of any publication from the public portal for the purpose of private study or research.

- You may not further distribute the material or use it for any profit-making activity or commercial gain

If the publication is distributed under the terms of Article $25 \mathrm{fa}$ of the Dutch Copyright Act, indicated by the "Taverne" license above, 


\title{
PUBLIC ENTREPRENEURSHIP AS INNOVATIVE MANAGEMENT STRATEGY IN THE PUBLIC SECTOR \\ A Public Choice-Approach
}

\author{
Paper Originally Presented at the 65th Annual Conference \\ of the Southern Economic Association \\ Fairmont Hotel, New Orleans, Louisiana, \\ United States of America \\ November 18-20, 1995 \\ First Draft \\ October 1995 \\ Revised Text \\ November 1996
}

\author{
J.G.A. van Mierlo \\ Associate Professor of Public Economics \\ Faculty of Economics and Business Administration \\ University of Maastricht \\ P.O. Box 616 \\ 6200 MD Maastricht \\ The Netherlands \\ Tel ++31 $433883641 / 3636$ \\ Telefax ++31433258440 \\ E-mail h.vanmierlo@algec.unimaas.nl
}




\section{Summary}

\section{Public Entrepreneurship as Innovative Management Strategy in the Public Sector. A Public Choice-Approach.}

\section{J.G.A. van Mierlo, University of Maastricht}

Bureaucratic service organisations in the public sector are increasingly loosing their previous comfortable monopoly positions in providing services to the public, due to radical structural changes in modern society. The public finance of their services by politicians ordering public services as elected representatives of the citizens-consumers is not longer guaranteed, and neither is the consumption of their services by the public. Government bureaucracy is forced to produce services under (quasi) competitive market conditions. In a competitive system of public service provision, government bureaucracies have to conquer new markets with new services (new product/market combinations). External management of their relations with funding politicians and with the service consumers is becoming vital for their survival.

'Public Entrepreneurship' is an important element of the necessary innovation of strategic management of government bureaucracies. In this paper, the concept of public entrepreneurship is elaborated. Public entrepreneurship originally is constructed by Osborne and Gaebler as a device to 'reinvent government'. The consequences of public entrepreneurship for their relations with political superiors and sponsors on the one hand, and their contacts with consumer-clients and interest groups on the other hand, are explored from the institutional perspective of public management reform in Western Europe. Public entrepreneurship combines elements of classical market entrepreneurship and elements of modern social entrepreneurship of institutions of private initiative. Public entrepreneurship imposes new challenges for bureaucrats operating between the political leadership of their bureau and the clients of the services provided by their bureau. Public entrepreneurship also causes new problems of political-democratic control. These challenges and problems are explored and some solutions are formulated. 


\section{Contents}

Summary

1. Introduction

2. Changes in society and in the organisation of government

2.1 Changes in society

2.2 Changes in government bureaucracy

3. Two levels of public entrepreneurship

3.1 Entrepreneurial government

3.2 Entrepreneurial bureaucrats

4. Public entrepreneurship in external management

4. 1 Public entrepreneurship

4.2 External management

5. Public entrepreneurship in contacts with citizens

5.1 In search of the clients

5.2 In search of more revenues

5.3 Possibilities for client registration

6. The dilemma between political management and client empowerment

7. Conclusion

References 


\section{Introduction}

In modern society the public sector is increasingly effected by the environment in which it operates. The organisation of government, the government bureaucracy, is no longer a closed system but is changing into an open system which becomes involved in continuous exchange relations with the environment. This environment includes the political system, in which political authorities operate as principals of bureaucratic agents, as well as society as a whole, in which individual citizens and their organisations operate as the consumers of the services and products provided by the bureaucrats. The external relations maintained by the bureaucrats with on the one hand the political managers and on the other hand the clients are subject to turbulent processes of change. By consequence, the 'external management of government becomes more important. This development afflicts the organisations of government (pure public organisations) as well as the institutions of non-commercial private institutions (semi-public organisations).

In this paper the relations between (semi-) public officials, or bureaucrats, and their clients, the individual policy consumers and their organisations, are explored. These relations are changing rapidly in the nineteen nineties. The concept of 'public entrepreneurship' is useful to develop a critical assessment of these changes. Public entrepreneurship becomes a key-concept in the strategic management of (semi-)public organisations (of government as well as of non-commercial private institutions). The consequences of public entrepreneurship for the daily operations and activities of employees in (semi-)public organisations are analyzed from the perspective of 'public choice theory'. The analysis applies to pure public organisations, the organisations of government or bureaucracies, but is also relevant for semi-public organisations, the noncommercial private institutions performing public tasks.

In section two an inventory of the main changes in society and in government bureaucracy is presented. For this purpose, the case of the Netherlands is used as an example for many countries in Western Europe. Two levels of public entrepreneurship are distinguished and discussed in section three. Section four deals with public entrepreneurship in external management of government. The exchange relations with the citizens-consumers-clients take a central position in public entrepreneurship. These exchange relations are explored in section five. Public entrepreneurship implies empowerment of the clients but this may result in conflicts with the political management of government organisations. This dilemma is considered in section six. Finally, some conclusions of the analysis are formulated in section seven.

\section{Changes in society and in the organisation of government}

During the last decades, fundamental changes have taken place in modern society of the Western world. These changes also have influenced the organisation of modern government. We summarise briefly both developments, starting with changes in the environment of government and then considering the changes in the organisation of government. The case of the Netherlands is used as an illustration of these changes.

\subsection{Changes in society}

The Netherlands is a highly organised country. Every field of daily life is characterised by a high level of organisation: churches, political parties, and social organisations. The explanation for this is the so-called 'Pillarisation' (in Dutch: 'Verzuiling'). In the Pillarisation-era (1920-1965) various population groups (catholics, protestants, socialists, and liberals) lived separated from each other. Political and social contrasts and conflicts were numerous and large. Political 'rules of the game' of Consociational Democracy (in particular elite-deliberations and consensus-building, see the theory of Arend Lijphart, 1986) assured conflict resolution and prevented secession and civil war.

At the supreme of Pillarisation, Dutch citizens and all their organisations were subordinated to their political leadership. The vertical and hierarchical organisation principle dominated their pillared system. Contacts between the separate pillars were maintained by the political leadership. Political leaders managed 
interest conflicts within their pillar as well as between the various pillars. The political masses were passive and obeyed.

In the nineteen sixties, technical and economic modernisation originated. Modern citizens lost their passiveness and became subject to political emancipation. Modern communication techniques (television) and private transport facilities (automobile) liberated citizens from their isolated position in society. Segregation of population groups came to and end. The pillared system broke down: a process of depillarisation changed the Netherlands radically within a decade, between 1960 and 1970.

This de-pillarisation had enormous consequences. Citizens did not longer obey passively their political leadership. Political leaders and parties were not longer master, but citizens increasingly evaluated their political leadership and parties on their policy performance. Political leaders and parties could not longer count automatically on the political support of their citizens, but had to gain this support by their performance.

Dutch society changed from a vertically and hierarchically organised and pillarized social system into a more horizontally and democratically social system. As the Dutch sociologist Abram de Swaan (1989) formulated, in the Netherlands (as well as in other countries of Western Europe) the 'command model' of organising society has been substituted by a 'negotiation model'.

\subsection{Changes in government bureaucracy}

The classical organisation of government is the bureaucracy. The theoretical model of the bureaucratic organisation has been developed by Max Weber (Weber, 1947). Bureaucracy is a formal organisational structure, featured by differentiation (division of labour), hierarchy and positions based on expertise. The classical bureaucracy is the best example of a vertical and hierarchical organisation. The bureaucratic model of Weber structural as well as behavioural characteristics. Behavioural characteristics are present in various devices of discipline and control. Formalisation and objectivisation of rules and regulations result in bureaucratic behaviour. The bureaucrat does his job precisely and consistently. Citizens are treated anonymously and impartially, 'sine ira et studio'. In this model, structural features are the most important. As structural features become more dominant, the bureaucratic organisation becomes more rational.

However, this does not hold for behavioural characteristics. Preciseness, consistency and impersonality may at a certain point prevent the realisation of formal objectives of the organisation; structural characteristics as differentiation, hierarchy and recruitment on basis of expertise may coincide with imprecise, inconsistent and personal behaviour of the bureaucrat. This is one reason why the classical Weberian model of bureaucracy is no longer dominant in scientific thinking about bureaucratic organisations, but has been confronted with other bureaucracy models, in particular the economic model of bureaucracy (see Niskanen, 1971). In the economic approach, bureaucracies are determined by budget systems, by not for profit-motives and by policy supplies as package deals (and not on a quid pro quo basis).

Four changes have taken place in the practical operation and functioning of government bureaucracies. The classical distinction between politics and administration (invented and advocated by Woodrow Wilson, the founder of modern public administration) is disappearing. Politics was considered to take the policydecisions, bureaucracy was responsible for policy-implementation. However, bureaucrats have a large advantage in expertise above politicians. Hence they have substantial political influence and power in the stage of policy preparation. In the implementation stage they also have much power and discretionary privileges, as technical implementation prescriptions cannot be determined completely and precisely in the decisionmaking stage.

Secondly, there has been an enormous quantitative growth of government. Big government resulted from an continuously increasingly appeal since 1945 on government as modern 'problem solver'. The expansion of the welfare state since the nineteen fifties was another factor in favour of big government.

Thirdly, the organisation of government has developed its own dynamics, both in quantitative and qualitative sense. The growth of government resulted in more growth, in particular as constantly new policies have to be developed and implemented in order to repair problems of previous policies that proved not to work (the phenomenon of 'policy-accumulation'). In this way, government was not longer considered to be a solution 
to the problem, but increasingly became part and even cause of the problem (as president Reagan stated in his inaugural address in 1980).

Fourthly, during the nineteen eighties government itself became subject to severe criticisms as a result of alleged seize of power by the bureaucracy, the quantitative growth of government, and the lacking problem solving capacities of government. After a long period of quantitative changes of government (more bureaucrats, more budgets, more government organisations, more government activities), the odds changed towards qualitative change of government: a smaller but better government became the parole in politics and society.

Citizens did not longer accept a big government which does cost large amounts of taxpayers money and does not solve the problems it is expected to solve. Citizens do also not longer accept that government organisations treat them as passive objects of public policies, instead of as active consumers, clients and even co-makers of public policies. Just as in modern society, in modern government the vertical and hierarchical command model of organisation is no longer valid. This classical model is substituted by a more modern model of horizontal and democratic organisation of government, in which negotiation and consultation are vehicles for decision-making (see Ostrom, 1973). Modern government is changing in reaction to the changing environment of government, i.e. modern society.

\section{Two levels of public entrepreneurship}

Three answers and solutions can be formulated to these problems of modern government. These three answers are at least partially determined by political ideology. The first answer is a radical one: the complete abolishment of government and a complete fallback on the market and price mechanism. However, we all know that there is still such a thing as 'market failure'. 'Government failure' is not a sufficient condition for surrender to market fetishism (see Wolfe, 1979; 1983; 1988). The second answer is more moderate one: more political control on government and bureaucracy. Political reformers, faced with the power of a bureaucracy, are always trying to solve this problem by making proposals to sharpen the external control of the bureaucracy: better organisation of parliament, more guidance and control of ministries and departments by ministers, better financial management, an ombudsman, systematic policy analysis, and so on. However, these measures are bureaucratic themselves and hence will have little effect: as limited as internal control of the bureaucracy is, will be external control. Bureaucracy cannot be fought with more bureaucracy.

The important lesson which teaches us a public choice-analysis of the problem of bureaucracy is, that the heart of the problem lies in two characteristics of bureaucracy: hierarchy and monopoly. The combination of both is extremely dangerous, because it results in bureaucratic power as is shown by the analysis of Van den Doel and Van Velthoven (1993: pp. 148-174). Hence, the hierarchical structure and the monopoly position of the government bureaucracy should be demolished. Monopoly should be substituted by competition and hierarchy by democracy.

The concept of 'public entrepreneurship' provides promising possibilities for radical reform of the government bureaucracy, especially by injecting mechanisms of competition and democratic control into public organisations. Public entrepreneurships seems to provide an escape from the dilemma between market fetishism on the one hand and bureaucratization on the other hand. An analytical distinction has to be made between two levels of public entrepreneurship: the level of the public organisation and the level of the public official. At the first level, the bureaucratic organisation of government has to be changed into a more entrepreneurial one. At the second level, the bureaucratic official and department within the government has to be changed into a more entrepreneurial one. Entrepreneurship as a characteristic of public organisations and as a characteristic of public officials can be connected by the sociological role-concept, as we will see below.

\subsection{Entrepreneurial government}


In a book which attracted world-wide attention, the American authors David Osborne and Ted Gaebler (1992) develop an extensive argument for a complete transformation of bureaucratic government into entrepreneurial government. In their view, government should not be abolished, but should be 'reinvented'. The classical model of government, employed in the Progressive Era and New Deal, is one of in-house program implementation and service delivery by hierarchically organized administrative departments, run by professional managers in accord with operational rules and fiscal checks. According to Osborne and Gaebler, this model was originally adopted to rid the country of inept patronage machines (just as in Europe the classical model of bureaucracy was introduced to rid of inadequate political favouritism!). However, in this era of global competition, instant communication, a knowledge-based economy, and niche-markets, such industrial era bureaucracy is alleged to produce mediocracy, inflexibility, and an obsession with control.

To replace this model of government, a new form of 'governance' should be created at all levels of government. In the United States, a programme for reform of federal government (NPR, the National Performance Review) under supervision of vice-president Al Gore has been launched in 1993, which has been inspired by the idea of 'entrepreneurial government', i.e., a government that is adaptable, responsive, efficient, and effective. Such a government must be able to produce high quality goods and services, be responsive to customers, be led by persuasion and incentives rather than command, empower clients, and - above all - be entrepreneurial.

Osborne and Gaebler formulated the following list of Ten Principles to achieve this fundamental transformation of the organisation of government:

1. Government should skilfully select alternatives to in-house delivery, such as contracting out, entering into public-private partnerships, and utilizing such devices as vouchers, volunteers, seed money, and quid pro quos. 2. Professional administrators should not run all aspects of programs but instead empower clients to participate in management by means of governing councils and management teams.

3. Competition should be injected into the governing process by such methods as bidding for tasks, internal rivalry among subunits, and competition among services for clients.

4. Agencies should minimize the number of rules by which they operate. To be eliminated are line-item budgeting, year-end fund expiration, and detailed job classifications. Once freed up, the organizations should dedicate themselves to a clear, one-niche mission.

5. Review of agency-performance and fund allocation should be based not on program inputs but on policy outcomes.

6. Clients must be regarded as customers. This calls for giving them choices, surveying their attitudes, making services convenient, training employees in customer contact, test marketing, and providing 800 numbers and suggestion forms.

7. Governments should not just spend money, but earn it as well, for example from use fees, shared savings, enterprise funds, entrepreneurial loan pools, and internally competitive profit centres.

8. Governments should not just deliver services to meet ends, but prevent needs from arising in the first place. Examples are fire prevention, preventative maintenance, recycling, antismoking campaigns, accrual accounting, and regional government.

9. Centralized institutions should become decentralized, with hierarchical control giving way to devolved authority, teamwork, participatory management, labour-management cooperation, quality circles, and employee development programs.

10. Governments should not attempt to achieve ends only by command and control, but also by restructuring markets. Illustrations are subsidized health insurance, incentives for downtown investment, and emissions trading.

So far these 'Ten Principles for Entrepreneurial Government', which have been formulated in somewhat exaggerating terms. Not the formulations, however, but the contents of these principles are relevant for discussion and criticisms. We will discuss Osborne and Gaebler's ideas in section six of this paper. Also we will pay attention to the criticisms to their approach. Suffice it to state here, that this approach shows the way to a politically radical but technically feasible solution for the classical problems of government. Some 
proposed solutions and principles may be just as classical as well, but the power of the recommended medicine lies perhaps in the combination in a cohesive package of reform measures.

The analysis and remedy of Osborne and Gaebler offer in particular a way-out of the just as classical as fatal dilemma between government and market. Government is identified with the inefficient public bureaucracy and the market is identified with the efficient private firm. This identification is false and invalid, as we all know. In turn, this misidentification results in the wrong conclusion, that bureaucracy is only present in the public sector and only can be fought by reducing government in favour of the market.

When there is no such one-to-one relation between both pairs of concepts: government-market and inefficient-inefficient, the failures of government cannot be fought by giving more room to the market. It is precisely this conclusion that is drawn by Osborne and Gaebler. They advocate not a necessarily smaller government, but a better government. An entrepreneurial government is to be preferred above a bureaucratic government, the problems of the bureaucratic government can be fought more successfully by an entrepreneurial government. The entrepreneurial government should be (re-) invented. This reinvention does not only offer an escape from the dilemma between government versus market in the Western World, but also may offer perspectives for a solution of the failing restructuring of former command economies in Central and Eastern Europe, which appear to be paralysed by this false dilemma (see Van Mierlo, 1995a and 1995b).

\subsection{Entrepreneurial bureaucrats}

The entrepreneurial government functions as the organisational framework within which the entrepreneurial bureaucrat operates. On the micro-level of public service delivery this results in an increasing demand for more client-orientation, and in connection with this professionalisation and productivity improvement of public organisations (see Van Mierlo, 1991a and 1991b). Client-orientation, professionalisation and productivity improvement are the key-concepts, by which the entrepreneurial bureaucrat in an entrepreneurial government organisation can be characterized. For a better understanding of the importance of the entrepreneurial bureaucrat, the following roles of government should be distinguished:

role 1: the government as regulator of society as a whole;

role 2: the government as financier, sponsor or subsidiser of activities in the non-commercial non-profit sector and in the commercial private sector;

role 3: the government as provider of public goods and services to citizens, or as public service deliverer. Concepts as 'government as entrepreneur' and 'entrepreneurship in the public sector' refer to the third role of government, that of public service provider.

The organisation of government, however, has some specific organisational features which cause some serious problems for the required client orientation in public service delivery. The following factors may impede improvement of client orientation (see Van der Hart, 1992: pp. 172-173; Brand, 1992: p. 185-196). -Government organisations have to serve several target groups of the population who have to be reckoned with and between whom sometimes choices have to be made;

-The translation of public tasks into specific public products is difficult: often more abstract varieties of public services are at stake which hardly can be recognised as products;

-Many times there is no clear demand for public goods and services: they are imposed on the citizens, resulting in forced and not in voluntary consumption. Sometimes these public services are producing favourable conditions, sometimes they are innovative;

-The organisation of government has its own specific culture of rules, habits, and laws. This legal culture offers little space for client-oriented formulations;

-In the organisation of government incentives to client-orientation are lacking. in case of a government monopoly, the client is dependent on the government an not the other way around;

-By nature, the bureaucrat is a-commercial: he is not recruited on basis of his sales capacities and he is not trained in acquiring such capacities;

-Selling policies is in the public sector limited to providing information, but in particular in government organisations this activity has a very low status; 
-When several target groups of the population are at stake, government organisations have serious problems in making strategic choices (target group selection), because for instance this might be considered as discrimination;

-Government is considered by the citizens as an organisational unity, whereas at the bottom level of government organisations, where contacts with clients are concentrated (street level bureaucracy), internal coordination is lacking or is insufficient;

-Government is not accustomed to think in terms of results: mostly, measurement of government performance is difficult.

In a democratic political system, client-orientation in bureaucratic service delivery is necessary, but this implies that all the barriers mentioned above have to be conquered. The contents of the concept of client orientation is very important in this respect. Client-orientation has a substantial significance on the strategic, the tactical and the operational level of government. At the strategic level, questions are involved such as: where has government to intervene, correct or render public services from a long term perspective? But also: where should government abstain from such intervention? And when there is a clear view on the required course of the government organisation in question, what are the precise target groups in which the organisation will be involved? At the tactical level, client-orientation implies the question: how to promote the particular policies of the government organisation? To answer this question, an adequate communication plan as well as the instrument of the marketing mix are indispensable. At the operational level, client-orientation refers to questions such as: how does the bureaucrat in his daily activities approach the client? What are the rules of behaviour which are (and should be) practised? The question for the specific contents of client-orientation can be answered by taking into explicit consideration the orientation of the government organisation towards the relevant target groups at the strategic, the tactical as well as the operational level:

-strategic: which fields of activity/target groups?

-tactical: how to promote the policies?

-operational; which approach to clients?

\section{Public entrepreneurship in external management}

In this section, public entrepreneurship in and external management of government organisations are discussed separately, because there is an analytical distinction between both concepts. However, both elements are mutually connected in practice.

\subsection{Public entrepreneurship}

Client-orientation of government organisations is necessary because of developments in modern society. Public organisations have to cope with increasing demands from both their political principals, by whom they are financed in exchange for their public service delivery, and their clients, the public to whom they provide their services. This double relationship, with their sponsors and with their clients, has important consequences for the external management of bureaucratic organisations. Classical hierarchical and vertical steering devices, in which one-way relations between the administrators and the administered exist using commands and orders, are substituted by modern democratic and horizontal steering devices, in which two-sided relations between both (groups of) actors exist using policy networks, negotiation and coalition structures, et cetera. The substitution of hierarchical steering models by democratic ones is not restricted to the external organisation of public institutions, but also takes place in their internal organisation. Modern society is becoming emancipated, hence not only individual citizens but also participants in public organisations are becoming more independent and autonomous.

Employees of bureaucratic organisations are behaving less in such a way as the classical bureaucrats in the Weberian bureaucracy model are assumed to do. Instead, the demand for an active and innovative 
entrepreneurship is increasing. Their services are no longer delivered automatically to a passive public, their services are no longer financed automatically by their political principals. Public organisations are no longer assured of instructions for public service delivery, and neither are the finance and the sale of these services. The finance and sale of public services are increasingly realised under (quasi-) market conditions (see for the theory of quasi-markets Savas, 1987; Le Grand and Bartlett, 1993). In addition to commercial markets in the private sector of the economy (markets for goods and services, labour markets and financial markets), in the public sector political and policy markets are developing, on which demand for and supply of public policies are matched. In many respects, these markets are becoming very similar to commercial markets. Public organisations and public officials have to behave more and more as entrepreneurs on these markets. Giving shape to entrepreneurship in bureaucratic organisations leads to an increasing demand for independent and innovative bureaucrats.

The demand for entrepreneurial bureaucrats complies to modern developments in public organisations, such as self-management, contract-management, intra-organisational decentralisation, various forms of privatisation, et cetera. These modern public management developments are inspired by comparable developments in the main elements of modern entrepreneurship in commercial business organisations in the private sector, such as strategic management, competition analysis, network building, environment and political market exploration, public affairs and lobbying, modern marketing techniques, product innovation, etcetera.

However, there are also important differences between public organisations and private enterprises. For their survival, private enterprises depend solely on the sale of their products on commercial markets. Their sales are determined by the demand for their products and their service deliveries. When their supply does not (or insufficiently) comply to demand, they will suffer sale problems. Their revenues will be threatened. if they do not adapt their supply to consumer preferences in time, they will go bankrupt inevitably. The survival of public organisations is not primarily dependent on their realised sales. Their revenues are not directly related to their sales. The consumers of their products do not pay themselves directly on a quid pro quo basis. The political principals take care for the payments of bureaucratic production. As long as there are so many linkage problems in the feedback mechanisms between clients and political principals (see the analysis of Van den Doel and Van Velthoven, 1993), decreasing sales of bureaucratic organisations do not result immediately in decreasing revenues. On the short run, the survival of bureaucratic organisations is not threatened.

The introduction of specific forms of privatisation, contract management and self-management in bureaucratic organisations aims at strengthening the linkages between sale and finance of public service delivery. As a consequence, the revenues of bureaucratic organisations will not longer consist of budgets allocated by political principals, but also of payments by their clients. Under full and complete privatisation, bureaucratic organisations become solely dependent from their sales on markets for their survival. In that case, public organisations ultimately do not differ from private enterprises and they stop to be public organisations: bureaucrats have become commercial entrepreneurs. In all intermediate forms, such as partial privatisation, contract management and self-management, the linkage between supply and demands is not realised through the market and price mechanism. Instead, managerial feedback mechanisms between sales to the clients and finance by political principals are established. In such public organisations, bureaucrats do not become real and commercial entrepreneurs, but they will become public entrepreneurs. In this respect, public or bureaucratic entrepreneurship differs from entrepreneurship in commercial private enterprises.

\subsection{External management}

Public entrepreneurship can be established in the internal management of public organisations (so-called 'intrapreneurship'), but also in their external management, i.e., in the contacts that these organisations maintain with individual citizens and their organisations (private service organisations and interest groups). We limit ourselves to the aspect of external management and hence discuss the topic of public entrepreneurship and not that of public intrapreneurship. 
The contents of the concept of 'social entrepreneurship', which is recommended as management strategy for non-profit institutions (see De Waal, 1991; De Waal, Schuyt and Verveen, 1994), can be useful to define the kernel of 'public entrepreneurship'. As a starting point it is stated, that public entrepreneurs are active and innovative. As a result of the external developments described above, a new constellation of the public administration is evolving. In this new constellation, there will be no longer a comfortable monopoly position of bureaucratic agencies with regard to their public service deliveries. The changing attitude and behaviour of both the political principals and the clients force bureaucratic agencies to think more in terms of competition. Movements at the demand side as well as at the supply side result in new market circumstances, in which the sale of public services and market shares have to be conquered actively. As a result, critical thinking about product/market combinations becomes crucial for the survival of bureaucratic organisations. In the new constellation, markets have to be conquered and maintained. For this purpose, strategic management of bureaucratic organisations is an essential activity and public entrepreneurship becomes an important management tool.

From the new starting point of thinking in terms of 'competition' and 'market conquests', public entrepreneurship involves the following elements;

1. at the demand side: exploration and analysis of (open or latent) problems and demands of society on the activity field of the public organisation in question;

2. at the supply side: exploration and analysis of problems and demands in the existing supply of services in the branch in which the organisation in question operates, and in particular in the existing supply of the organisation itself;

3. matching of demand and supply by adapting the supply of the organisation in question to the actual or potential demand from the policy field/market;

4. using a network of contacts with other involved institutions, such as political principals, interest groups and service organisations as representatives of clients, and competing bureaucratic organisations, under simultaneous development of this network.

The first element of public entrepreneurship consists of active 'market exploration' and 'market canvassing' at the demand side. For what goods and services open or latent demand can be discovered, which the public organisation in question may provide? The second element implies a 'competition analysis' and environmental analysis at the supply side. Three questions have to be answered. Are there other public organisations which already satisfy these wants and needs, en if so, how do they do that? These other organisations can be competitive bureaucratic organisations, but they also may be non-commercial private institutions (non-profit) or even commercial enterprises. The next question is: does the provision by other organisations leave some room for new supply by the organisation in question? Finally: which possibility does this organisation have to undertake new supply of goods and services?

The third element regards the feedback of the actual or potential demand to a specific public service delivery by the organisation in question. The public entrepreneur operates as a broker or matcher between demand and supply. In this respect, the following questions are relevant: is a purchasing-power present or can such power be developed or evoked? Is this purchasing-power executed by the potential clients themselves (paying for their own purchases), probably in combination with partial finance by political sponsors (government subsidisation) and by interest groups. Is the organisation in question able to react adequately to this demand by rearranging or expansion of its own supply?

The fourth element of public entrepreneurship refers to the use of policy networks necessary for performing the matching function. The new (quasi-)market constellation of public service delivery requires that suppliers have consultations among themselves, build coalitions and cooperative arrangements, and organise market agreements (market division, price- and quality agreements, standardisation) among themselves, as well as with their political sponsors and with their clients and their representative organisations. Demand/supply relations on an innovated (quasi-) market for public service delivery are no longer temporary and incidental, but will be institutionalised in various forms of new institutional arrangements. Networkbuilding is a powerful vehicle for playing an important role in this process of institutional re-arranging. 
Alternative arrangements for providing public services are emerging at high speed in the nineteen nineties everywhere in the Western world. Savas (1987: pp. $58 \mathrm{ff}$.) points out, that the construction of these alternative arrangements involves four separate questions to be answered:

1. Who is the arranger? The arranger selects, assigns and authorizes the producer.

2. Who is the producer? The producer delivers the service to the customers.

3. Who is the consumer? The consumer takes the services delivered by the producers.

4. Who is the financier? The financier pays for the services delivered by the producers to the consumers.

In the nineteen nineties, these four functions in public service delivery are no longer performed simultaneously by the government and its bureaucratic organisations in an monopoly position. Every function can be performed by different organisations, be it pure public, semi-public or non-profit, and pure private. Hence mixed and complicated institutional arrangements emerge. This development offers new chances and possibilities for public or bureaucratic entrepreneurs, who can play an important role in the external organisation of such mixed and complicated institutional arrangements.

\section{Public entrepreneurship in contacts with citizens}

Public entrepreneurship in contacts with clients involves three elements: the search for clients, the search for revenues, and possibilities for customers registration.

\subsection{In search of the clients}

What does public entrepreneurship mean for public officials who are involved in public service delivery to client groups (the street level and front office bureaucrats)? In the classical situation of bureaucracy, the client came into contact with bureaucratic agencies through a system of formalised entry criteria, intake procedures, et cetera (see De Waal, 1991: pp. 159-175, for an elaboration of this development in the non-profit sector of non-commercial private institutions). The client was not approached from a holistic perspective, but only with regard to his part of 'client-demand', as far as this demand fitted in the regulations and the customer categories which the supplying organisation, again on basis of bureaucratic rules, was allowed to offer services. By consequence, this client-demand belonged to the domain and competence of the bureaucratic professional and not to the domain and competence of the management of the organisation. Hence, the client-demand was hardly object of the strategic management of the organisation.

After the formal definition of client-demand according to the bureaucratic rules and procedures, this client-demand was in the first instance an operational problem. This operational problem was taken care of by the operational management within the side-condition of available resources. Often this operational management was not defined as a separate category of functions in the organisation, but was part of the other professionals. On the other hand, the management was responsible for policy-formation, but within the limited framework decided upon by political decision-making. To call this activity 'strategic management' goes much too far. The kernel of management exertion was limited to 'condition creating policy'. This implies that neither with regard to content nor with regard to organisation there was any relationship between the clients of the organisation and the management of the organisation. This development of non-existing relationships reached a climax in the nineteen seventies.

In the nineteen seventies, the crisis of the welfare state became apparent. Since then the competition between public services for scarce resources sharpened and the client was rediscovered as a strategic factor. From then on, the necessity to build direct relations between the client and the strategy and management of the agency increases. The bureaucratic agency directs its attention more to its services and to its market, including the competitive situation on this market, and it defines its function from this perspective and not longer on basis of the requirements and the rules of the political principal. In order to do this, two alternatives are available:

a. the search for more main financiers outside the market, such as funds, private firms, private sponsors, et cetera; 
b. the generation of more revenues on the market, for example by applying the Robin Hood-strategy: selling services to market-segments with more purchasing-power and cross-subsidising services to market-segments with less purchasing-power (so-called 'cream-skimming' and 'cherry-picking').

This development is stimulated by the political principals as financiers, who for example increase artificially the purchasing-power in some parts of the market by 'client-bound budgets', or who stop to decrease artificially this purchasing-power in other parts of the market by decreasing the tax and social security burden or by changing the distribution of this burden, with simultaneous cutbacks of the government subsidies. The traditional system involved a relatively expensive and artificial mechanism of 'pumping around money': first levying taxes and social security premiums, than transforming these revenues in subsidies and regulations for public services, than arranging and controlling these services, and finally regulating the access to these services for client-groups with less purchasing-power. With the last step, the circle is closed, because this small purchasing-power is caused at least partially by the high tax and social security burden.

In the nineteen nineties, this bureaucratic mechanism is replaced by a somewhat corrected (quasi-) market mechanism. In this new constellation of public service delivery, planning supply-finance by government is substituted increasingly by a system of demand-finance, respectively a finance-system which gives the bureaucratic organisations in question more room to manoeuvre and more discretionary power. At the macroeconomic level, the financial 'pumping around circuit' is shortened drastically (the so-called 'balanceshortening'). Due to its slow and bureaucratic, but simultaneously also systematic and objective pumping around system, the government is very able to discover gross gaps in the total palette of public services, and to provide resources and incentives to fill these gaps. For this purpose the government is assisted by various bureaucratic agencies as well as private institutions, which explore the different possibilities for subsidisation and recommend various problems and gaps for subsidisation. As more or less independent business-units they undertake a first gross marketing exercise for the government as 'concern-organisation'.

However, there is an increasing recognition that at this very moment the stage is reached for a more 'refined and creative marketing'. In marketing terms public officials are implied who show an active involvement in developments in society and who take a central position in the market. These officials are not only the salesmen of goods and service defined somewhere else, but they are also initiators and entrepreneurs in the creation of new public services which comply better to consumer demands. The central question becomes: how to generate more revenues? This question has everything to do with the increasement of the independence and autonomy of public organisations. Even private firms have only limited room to manoeuvre when they have to deal with only one large financier, for example a house-bank.

With this problem, we come back to the question: who is the client of bureaucratic organisations? For private firms and enterprises, in most case this is not a difficult question to answer. For, them another problem is more urgent. Which clients have to be served and which clients do not? Which clients offer the best perspectives for making a profit? This is the problem of 'market segmentation'. In the public sector, in which government organisations operate, this question is much more difficult to answer, but sometimes it is very easy or obvious. The answer depends on the type of organisation under investigation. In this respect, two factors are relevant:

a. the degree to which the organisation has direct or indirect contacts with the public;

b. the degree to which the client pays for bureaucratic services.

Both factors can be combined into a matrix (see figure 1). This matrix contains four quadrants (see Van der Hart, 1992: pp. 176-178).

Figure 1. Client orientation of government organisations

Degree to which a price is

paid for public services

Degree of contacts
Nihil

$100 \%$

I 
with the public

$\begin{array}{ll}\text {-hospitals } & \text {-mail service } \\ \text {-police } & \text {-railways } \\ \text {-education } & \text {-libraries } \\ \text {-national } & \text {-music theatres }\end{array}$

ombudsman

$\begin{array}{ll}\text { Low } & \text { III } \\ & \text {-municipality } \\ \text { agencies } \\ \text { departments of } \\ \text { ministry of } \\ \text { education }\end{array}$

IV

-public pension

fund for civil

servants

-public water

authorities

-public utilities

Quadrant I consists of public organisations which maintains contacts with the public. however, the clients do not have to pay for the public services offered. The survival of the public organisation is not dependent directly on the clients (at least not on the short run). Hence, the introduction of client-orientation will take much effort. These organisations are featured by a high internal orientation and the customers have to adapt. Examples are hospitals, police services and educational institutions. As long as their services are not paid directly by the consumers but are financed by budgets allocated by the political principals, the do not consider their clients but their principals to be customers.

In quadrant II all those public organisations are located which combine in their public service delivery a strong contact with the public with a high degree of direct payments by their clients. Examples are the public mail services, the railway companies, the libraries, the music theatres, et cetera. These public organisations are either privatised institutions (public enterprises) or internally facilitated staff departments (internal facilitation). In this quadrant client-orientation is a sine qua non-condition for survival, at least in the long run. The revenues of these public organisations are linked directly to the clients. This quadrant can be considered the transition stage between pure government organisations and pure business organisations. The only difference is the ownership situation.

In the following two quadrants (III and IV) client orientation shows more difficulties. In quadrant III introduction of client orientation is most problematic. Here mainly policy-supporting and policy-preparing government agencies can be located. The products of these agencies are not manufactured directly for clients, but for other agencies and organisations in the policy-process. These organisations are responsible for 'intermediate production'. In turn, these intermediate products are used as resources for the manufacturing of final products which are offered to the clients. here contradictions and tensions may arise between clientorientation towards the citizens (the final customer) and client-orientation towards the political management (the original principals). A certain balance between both interests is necessary. A fundamental reflection on the function, the products and the various target groups of the organisation may provide clearness and may lead to a cohesive set of behavioural rules. Every public organisation and government agency is able, even without direct contacts with the public, to distinguish on basis of a thorough analysis one or more target groups for which public services are delivered. In the private sector, also intermediate production takes place, which causes comparable problems and for which solutions have been formulated: transfer pricing, overhead values analysis, value chain analysis, et cetera.

Quadrant IV contains public organisations which do not have direct contacts with the public but which receive direct payments for their services. One could think of public pension funds for civil servants (in the Netherlands: ABP) and of some public authorities performing a specific public task, financed by taxes, premiums, retributions, public prices, et cetera, for example public water authorities and public utilities. The financial aspect determines largely the policy-contents and the public organisations have more a financial orientation then a client-orientation. However, there are only as few organisations receiving direct payments for their services and still not having direct contacts with the public. Of course, there are always some direct 
contacts with the clients. The degree of government monopoly and the technical characteristics of the services delivered determine, to which degree contacts with the clients are necessary to generate revenues.

The desire for more client-orientation requires that the results of the activities of bureaucratic organisations are made visible. If one succeeds to make the results of the fulfilling of functions for client groups visible, this function fulfilment can be corrected and adapted better and more easily (feedback!). In the market sector, private commercial organisations are managed by the reactions of consumers to price signals. The willingness to pay a certain price is considered to be a positive valuation of the supply. Figures about sales and market shares are applied as steering variables by the management. Because such clear price signals are lacking in bureaucratic service production, other devices have to be developed, for example performance measures such 'effectiveness measurement'. Effectiveness measurement implies the following elements (see Baakman and van Mierlo, 1991: pp. 131-147; Van der Hart, 1992: pp. 178-179).

1. Making visible the efforts made, in hours (input, for example the number of labour hours necessary for producing a particular service) or in achievements in units (output, for instance the number of produced brochures in an information campaign).

2. Range measurement: determining which part of the intended client-groups or user-groups are reached with bureaucratic service delivery.

3. Valuation measurement: investigating how the consumers of bureaucratic services value the organisation and the products, with regard to their usefulness as well as to the manners and the formats of the presentation of the supply to the client (valuation measures).

4. Result measurement: determining the final results of the efforts made in relation to the objectives of the organisation (effect measures). Real result measurement is difficult, because in many cases effects of specific activities or measures cannot be isolated and cannot be modelled in a causal relationship.

Effectiveness measurement forces automatically to an adequate identification of target groups. This is particular true for range measurement, valuation measurement and result measurement. Organisations paying explicit attention to these activities will also have a more favourable internal climate and attitude for client-oriented operating. The price as a signal for the degree of consumer satisfaction can at least partially and as a proxy be substituted by a specific form of effectiveness measurement. The search for and experiments with measures for effectiveness of bureaucratic organisations may result itself in a shift towards the quadrants II and IV in figure 2. In these quadrants, bureaucratic organisations are located in which client-orientation can be introduced more easily than in bureaucratic organisations located in the quadrants I and II.

Figure 2. Client orientation and effectiveness measurement

Degree to which one succeeds

in measuring the effectiveness

of service delivery

Degree of contacts

with the public
Nihil

$100 \%$

High

I

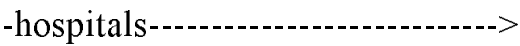

-education----------------------------->

Low 
ministry of

education

\subsection{In search of more revenues}

Client-orientation is for bureaucratic organisations a means to generate more revenues from bureaucratic service delivery. The generation of more revenues may contribute to the survival of the organisation in question. The bureaucratic management may aim at revenue generation in cooperation with the bureaucratic professionals, by applying all available instruments that are discussed in the literature on business administration (see De Waal, 1991: pp. 169-170). As revenues are more insecure or the market is more unknown, the financial risks will increase. A valid financial prognosis and knowledge of this problem field in the mind of the management is of great importance. In theory, the generation of more revenues can be directed on two dimensions of the activities employed by the bureaucratic organisation: the dimension of the client-groups and the dimension of the supplied services. Combination of both dimensions results in a so-called 'product/market combination' (PMC) (figure 3). On the horizontal dimension a distinction is made between the present market and the new market to be conquered. On the horizontal dimension a comparable distinction is made in the supplied services, between present services and new services to be developed.

Figure 3. Increasement of revenues from markets

$\begin{array}{llll}\text { Client-groups } & \begin{array}{l}\text { Present } \\ \text { client-groups }\end{array} & \text { New } & \\ \text { client-groups }\end{array}$

Services

Present services

New services
Market deepening

Product broadening
Market broadening

Market conquering

In a new constellation of public service delivery in the nineteen nineties, many examples can be found which fit in a strategic policy to generate more revenues. These examples can be translated in the market-strategic terms specified in figure 3 . Application of the original scheme of figure 3 to the practice of public service delivery, for example a municipal social service agency, results in the scheme presented in figure 4 .

Figure 4. Increasement of revenues from the market of municipal social service agencies

$\begin{array}{llll}\text { Client-groups } & \begin{array}{l}\text { Present } \\ \text { client-groups }\end{array} & \text { New } & \\ & \text { client-groups }\end{array}$

Services

Present services

Market deepening:

Higher user-charges
Market broadening:

Accompaniment of 
for specific services

New services
Product broadening:

Mediation in re-schooling

of unemployed employed searching

another job

('job hunting')

Market conquering:

Mediation in re-schooling

of employed searching

another job

Every larger Dutch municipality has a social service agency, responsible for three activities: providing a social security allowance for those unemployed more than a certain period, providing specific care in kind, and providing a job if possible. Such a local social security agency could decide to levy higher user charges from present clients for present services. This would imply just a raise in public prices. In addition, present services could be offered to new clients: market broadening. An example would be the active accompaniment of individual citizens already employed but wanting to change jobs ('job hunting'). Moreover, new services could be offered to present clients, for example mediation in re-schooling activities for unemployed, in order to improve their starting position on the labour market: product broadening. Finally, these new services also could be offered to new clients, for example to employed citizens looking for another job: market conquering. In all these three examples of market broadening, product broadening and market conquering, cooperation with other involved organisations, such as public labour agencies and private labour mediation firms would be obvious. In that case, network building would be at stake.

\subsection{Possibilities for client registration}

Besides the generation of more revenues from the market, public entrepreneurship implies the practising of new forms of client registration and representation to the bureaucratic organisation. In the Netherlands and other Western European countries the problem of client registration has become actual due to the process of de-pillarization (clients do not longer buy their services automatically from organisations belonging to their own pillars) and of the uprise of the critical consumer (modern consumerism). This development also has taken place in bureaucratic service delivery and this results in the following question: how do public organisations maintain their relations with the client/costumer? In this problem field the following elements are relevant (originally formulated by De Waal, 1991: p. 171, for non-commercial institutions of private initiative).

a. The market share, i.e. the relation between present (groups of) clients and potential clients, in both quantitative and qualitative respect: which groups are over- or under-represented? This refers to the actual relationship maintained with the client-population, for which the public services are provided. Does the bureaucratic organisation reach the clients that it is assumed or obliged to reach? Who make use of the public provision? What are the causes of significant deviations? Here the analysis of the effect of achievements and behaviour of bureaucratic organisations towards their clientele is at stake. This would be an exciting topic of public entrepreneurship.

b. The approach, i.e. how do clients feel treated by the bureaucratic organisation, or what is the image of the bureaucratic organisation in this respect in the opinion of the client-population it is assumed or obliged to service? Here the relationship between the whole client-population (including family, friends and acquaintances) and the bureaucratic organisation is at stake. Relevant parts of this problem are:

-forms to be filled in;

-application sheets;

-desk-, reception-, and telephone treatment and telephone personnel;

-accommodation;

-waiting lists and waiting times (the queuing-problem!); 
-reference procedures and behaviour;

-internal and external information.

c. The after sale-service, i.e. the follow up for clients and their family when the bureaucratic services are consumed.

d. The daily policy-influencing, i.e. the possibility for a specific client to manage that the policies decided upon in the organisation will be maintained flexible and adaptive in the organisation. This is closely related with the quality and the clearness of the organisation and in particular with the degree of decentralisation of powers and the freedom for discretionary behaviour at the work place. In case of public services which take a long time (for example in health care), this is very important in the relation between client and bureaucratic organisation.

e. The structural policy-influencing, i.e. the extent to which the client through indirect constructions or even by direct elections is represented in organs having formal powers with regard to policyprocedures. This could be arranged by a client- or user-council, but also by taking part in participatory management of the bureaucratic organisation.

Referring again to the example of the municipal social security agency, with regard to each of the mentioned parts of client-registration and participation their are many possibilities. The market share could be increased, for example by improving the bureaucratic competence of citizens but also by making use of better and more refined marketing of services. The approach of the clients could be improved on all distinguished points (see the list under $\mathrm{c}$.). The after sale-service deserves more attention. The daily as well as the structural policyinfluencing could be given a higher priority, for example through complaint procedures, but also through clients-councils. Public entrepreneurship requires a high priority for these matters at the level of the strategic management of the bureaucratic organisation in question.

\section{The dilemma between political management and client empowerment}

Client-orientation instead of task-, function- or product-orientation, in the public service delivery to clients has also to cope with some serious problems. Factors which may impede improving client-orientation of government organisations already have been discussed above. These factors may cause serious problems which not all might appear to be solvable. It is necessary to recognise these factors right in time and to handle them with prejudice. These factors cam be summarised as follows.

1. Problems in the organisational structure:

-the lack of incentives to client-orientation;

-the lack of recruitment on and training in client-orientation;

-the shortcoming of internal coordination mechanisms.

2. Problems in the organisational culture:

-the legal orientation of the bureaucratic organisation;

-the low status of information and selling activities;

-insufficient attention for thinking in terms of results.

3. Problems in the definition of public products:

-abstract and heterogeneous services;

-insufficient room for performance measurement.

4. Problems in the contacts with the clients:

-forced and imposed consumption of public services instead of free consumer choice (the problem of monopoly);

-the supply to several target groups, resulting in selection problems;

-the impossibility of target group selection because of alleged discrimination.

All these problems might result in an additional pressure on the strained relationship between political principals and hierarchical superiors in the bureaucracy (arrangers and financiers) on the one hand and the clients (the consumers who have to pay for public service delivery) on the other hand. Public entrepreneurship is involved in two simultaneous feedback mechanisms. In the classical bureaucracy there is only a 
(complicated) feedback mechanism through the channels of the political process of representative democracy, with all dangers of government failure. In the market place, direct feedback mechanisms are present between consumers and producers through direct exchange and quid pro quo relations. Both feedback mechanisms are combined in case of bureaucratic or public entrepreneurship (see figure 5).

Figure 5. The double feedback mechanism in public entrepreneurship

Feedback by the political

process: political principals/

sponsors allocating budgets

Input

Output

Civil Servants as

Bureaucrats

PUBLIC

ENTREPRENEURSHIP

Civil Servants as

Entrepreneurs

Input

Feedback by the market
process: consumers paying
public prices and user charges

Both feedback mechanisms may produce different and contradicting results. When the preferences of the clients are unclear or ambiguous, or between different client groups even mutually contradicting, the public entrepreneur has to cope with a serious problem. However, when the demands of the political principals are opposite to the preferences of the citizens/consumers, it will become almost impossible for the public entrepreneur to do a proper job. The yet classical public choice question becomes relevant then: whose 
preferences will be the guide for public provision, the preferences of the political principals or the preferences of the citizens/clients? Subsequently, when the public entrepreneur has made up his mind and has made his decisions, with which criteria will his operations and activities will be judged, and who decides upon these criteria? Whose preferences count and how much will remain of the independent responsibility and autonomy of the bureaucrat, as once has been formulated as a central postulate, a central rule of the game in the Weberian model of bureaucracy.

When such contradictions and tensions are at hand, the public entrepreneur does wise to start consultations with his bureaucratic superiors and with his political principals. An escape of the dilemma between political management and principals on the one hand (authority by the political process) and client empowerment on the other hand (authority by the market process) should be investigated seriously. Choices have to be made, decisions have to be made, which have to be supported by the political management of the bureaucratic organisation in the subsequent stages of public service delivery.

This brings us back to the pros and cons of the central philosophy of public entrepreneurship. The concept of public entrepreneurship has been criticised severely by many, in particular by specialists in the field of public administration (see the special volume of Public Administration Review on 'Reinventing Government', March/April 1994). In a book review in Public Administration Review of Osborne and Gaebler's Reinventing Government, Charles Goodsell (1993: pp. 85-87) criticises their approach and ideas of entrepreneurial government and public entrepreneurship in a rather fundamental way. In reaction to their ten principles of public entrepreneurship, Goodsell formulated his 'Ten Principles of Rediscovered Government':

1. Through their elected representatives, the people are in charge of American governance, not the entrepreneurs.

2. Government is intended to serve the public interest, not create unspent reserves or feed entrepreneurial egos.

3. Government must operate according the Constitution and laws of the land, not niche mission statements.

4. Government can enter into partnerships with private entities as long as it is the senior partner.

5. Government should be flexible and innovative, but also publicly accountable.

6. Performance results must be demanded in government, but also respect for the public employees who make them happen.

7. In government, private managerial conduct must comply to the non-private ideals of equal opportunity and open scrutiny.

8. Simplification of rules is fine, but not dilution of the principles of comparable treatment and due process.

9. Reduction of fiscal constraints is acceptable, but not a lessening of requirements for stewardship over the public's money.

10. Public problems should be dealt with publicly, but not as to give away the store to those who will benefit.

In sum, Goodsell argues that public administration is not obsolete. Nobody has really argued it is, not even public choice theorists. However, if there would rise conflicts and contradictions between Osborne and Gaebler's ten principles for public entrepreneurship and reinventing government and Goodsell's ten principles for classical bureaucracy and rediscovering government, Goodsell makes his choice. That is one way to solve a potential dilemma.

Another way could be to investigate seriously the validity and presence of such contradictions, to determine which principle has priority in case of inevitable conflicts, and to balance and compromise between both principles if possible. The real question is, whether both approaches, resulting in two different lists of ten principles, can be reconciled. If such a reconciliation is not possible, a lexicographic ordering of the two approaches could be considered, in which the one point of view functions as a prerequisite for the other. Economists have learned to optimise, not to maximise, but given the amount of available information optimising and maximising is the same thing, as Riker and Ordeshook (1973) argued. In the case of public entrepreneurship, this may be a truism too.

\section{Conclusion}


Modern society is subject to fast economic and technical developments. The information revolution, ecological problems, reorganisation of the labour system, European unification, Eastern European transition to a market economy, are as many catchwords of these developments. Government experiences not only the consequences of these developments, but is also involved in attempts to steer these developments.

In the first place, this has consequences for the external management of public and bureaucratic organisations, i.e. for the relations with society (citizens, producers and consumers): hierarchical and vertical steering models (in which one-way relations are maintained between the administrators and the administered) are replaced by democratic and horizontal steering models (in which two-sided relations between both actors are maintained through policy-networks, negotiation and coalition structures, et cetera). Entrepreneurial government is the key-concept of the nineteen nineties. In addition, there are consequences for the internal management of public and bureaucratic organisations. Substitution of hierarchical by democratic steering models is not limited to the external management of these organisations, but also takes place in the internal management. Not only society emancipates, participants in public and bureaucratic organisations also emancipate. With this statement, the 'entrepreneurial bureaucrat' comes into sight.

Participants in public and bureaucratic organisations can behave less and less like classical bureaucrats. From them, active and innovative entrepreneurship is required increasingly. This means that they have to behave more and more like a modern entrepreneur on the political (quasi-) market as well as on the economic market. Required entrepreneurship in bureaucratic organisations results in a growing demand for entrepreneurial, independent and innovative bureaucrats. This growing demand corresponds with recent managerial developments in bureaucratic organisations, such as self-management and contract-management, intra-organisational decentralisation, various forms of privatisation, and so on. These developments in public management are inspired by the classical elements of classical entrepreneurship in commercial business organisations, such as strategic management, competition-analysis, network-building, environment and political market exploration, public affairs and lobbying, modern techniques of market canvassing, product innovation, et cetera.

Bureaucratic or public entrepreneurship is not only necessary to adapt to developments at the demand side, but is also stimulated by new forms of competition at the supply side of public service delivery. Besides bureaucratic government organisations, non-commercial private non-profit institutions have undergone a process of revitalisation. They employ the concept of 'social entrepreneurship' to reshape the service delivery to their clients. Even commercial private business organisations in the market sector have the discovered the market for public service delivery, on which traditionally government had a monopoly position. Various forms of competition but also of cooperation (market division, strategic alliances and network-building) between these three sectors at the supply-side of public service delivery is possible, but for every outcome bureaucratic organisations need more public entrepreneurship.

Public organisations, however, differ from commercial private and business organisations. Therefore, public entrepreneurship differs from commercial entrepreneurship. Public and bureaucratic entrepreneurship implies, that entrepreneurial activities are undertaken but that they do not result in production for a real consumer market, with all corresponding elements of the market/price-mechanism. Public entrepreneurship contains a combination of public service delivery (with the public interest as policy objective and compass) with quasi-market conditions (resulting in effectiveness and efficiency in the implementation and production). The effects of public and bureaucratic entrepreneurship on the contacts and relations which public officials maintain with (groups of) the public and the clients are investigated in this paper. This will be an important and interesting topic for further scientific research (public choice, public administration and business administration/economics) for many years to come, as alternative institutional arrangements for public service delivery will stay on the political agenda. 


\section{References}

Baakman, N.A.A. en J.G.A. van Mierlo, 1991, Overheid en Onderneming. Een Inleiding, Groningen.

Brand, G., 1992, De overheid als dienstverlener. Kwaliteit en klant, in L.Th.R. Wijchers, L.A.F.M. Kerklaan en W.F.G. Mastenbroek (red.), Kwaliteitsmanagement in de Dienstverlening. Continue resultaatverbetering als managementstijl, Deventer 1992, pp. 185-196.

Doel, J. van den en B.C.J. van Velthoven, 1990, Democratie en Welvaartstheorie, (derde, geheel herziene druk), Alphen aan den Rijn.

Doel, J. van den and B.C.J. van Velthoven, 1993, Democracy and Welfare Economics, second edition (first edition 1979), Cambridge.

Goodsell, C.T., 1993, Reinventing Government or Rediscover it?, in Public Administration Review, January/February 1993, Volume 53 Number 1, pp. 85-87.

Hanusch, H. (ed.), 1983, Anatomy of Government Deficiencies, New York.

Hart, H.W.C. van der, 1992, Overheidsorganisaties en hun klanten. Strategie, tactiek en uitvoering, in L. Th.R. Wijchers, L.A.F.M. Kerklaan en W.F.G. Mastenbroek (red.), Kwaliteitsmanagement in de Dienstverlening. Continue resultaatverbetering als managementstijl, Deventer 1992, pp. 171-184.

Korsten, A.F.A., F. Kluytmans, T.W.P.M. van der Krogt en A. Sorber (red), 1991, Overheidsmanagement en de menselijke factor, Congrespublicatie 1991 van de Vereniging voor Bestuurskunde, 's-Gravenhage.

Le Grand, J. and W. Bartlett (eds.), 1993, Quasi-Markets and Social Policy, Basingstoke and London.

Lijphart, A., 1986, Verzuiling, pacificatie en kentering in de Nederlandse politiek, zesde druk, Amsterdam.

Mierlo, J.G.A. van, 1991a, Ambtelijke posities en rollen in verandering: een overzicht, in A.F.A. Korsten, F. Kluytmans, T.W.P.M. van der Krogt en A. Sorber (red), 1991, Overheidsmanagement en de menselijke factor, Congrespublicatie 1991 van de Vereniging voor Bestuurskunde, 's-Gravenhage 1991, pp. 157-181.

Mierlo, J.G.A. van (red.), 1991, Particulier Initiatief in de Gezondheidszorg, Assen/Maastricht.

Mierlo, J.G.A. van, 1993a, Ambtelijk ondernemerschap als innovatieve managementstrategie in de publieke sector, Research Memorandum 93-007, Rijksuniversiteit Limburg, Maastricht.

Mierlo, J.G.A. van, 1993b, Ambtelijk ondernemerschap in contacten met klantgroepen en belangengroepen, in A.J.G.M. Bekke, F. van Dijk, A.P.M. Schrijvers, N. Wijma en G. Wijnen (red.), Handboek Management in Overheidsorganisaties, Alphen aan den Rijn 1993, pp. A3140-1 - A3140-26.

Mierlo, J.G.A. van, 1995, Learning Processes between Public and Private Organisations, Research Memorandum RM 0/95-0xx, Meteor, Faculty of Economics and Business Administration, Limburg University, Maastricht December 1995.

Mierlo, J.G.A. van, 1995, Public Entrepreneurship as an Escape from the Privatisation Dilemma in Economies in Transition, Research Memorandum RM/95-0xx, Meteor, Faculty of Economics and Business Administration, Limburg University, Maastricht December 1995. 
Niskanen, W.A., 1971, Bureaucracy and Representative Government, Chicago.

Osborne, D. and T. Gaebler, 1992, Reinventing Government. How the Entrepreneurial Spirit is Transforming the Public Sector, Reading MA.

Ostrom, V., 1973, The Intellectual Crisis in American Public Administration, Alabama (revised edition 1974).

Public Administration Review, 1994, Reinventing Goverment: A Mini-Forum, Volume 54 Number 2, pp. 95-128.

Riker, W.H. and P.C. Ordeshook, 1973, An Introduction to Positive Political Theory, Englewood Cliffs, N.J.

Savas, E.S., 1987, Privatization. The Key to Better Government, Chatham N.J.

Self, P., 1993, Government by the Market? The Politics of Public Choice, Basingstoke and London.

Swaan, A. de, 1989, Zorg en de staat, Amsterdam.

Waal, S.P.M. de, 1991, Cliëntgericht besturen in de gezondheidszorg. De nieuwe legitimatie, in J.G.A. van Mierlo (red.), Particulier Initiatief in de Gezondheidszorg, Assen/Maastricht 1991, pp. 159-176.

Waal, S.P.M. de, Th.N.M. Schuyt en P.A. Verveen, 1994, Handboek Maatschappelijk Ondernemerschap, Houten/Zaventem.

Walsh, K., 1995, Public Services and Market Mechanisms. Competition, Contracting and the New Public Management, Basingstoke and London.

Weber, M., 1947, The Theory of Social and Economic Organization, (transl. Parsons/Henderson), New York.

Wijchers, L.Th.R., L.A.F.M. Kerklaan en W.F.G. Mastenbroek (red.), 1992, Kwaliteitsmanagement in de Dienstverlening. Continue resultaatverbetering als managementstijl, Deventer.

Wolfe, Ch. jr., 1979, A Theory of Nonmarket Failure, in Journal of Law and Economics, Vol 22, No. 1, pp. 79-82.

Wolfe, Ch. jr., 1983, 'Non-Market Failure' Revisited: The Anatomy and Physiology of Government Deficiencies, in H. Hanusch (ed.), 1983, Anatomy of Government Deficiencies, New York.

Wolfe, Ch. jr., 1988, Markets or Governments. Choosing between Imperfect Alternatives, Cambridge Mass. 